\title{
Bicarbonate Evokes Reciprocal Changes in Intracellular Cyclic di-GMP and Cyclic AMP Levels in Pseudomonas aeruginosa
}

\author{
Kasidid Ruksakiet ${ }^{1,2}{ }^{\oplus}$, Balázs Stercz ${ }^{3} \oplus$, Gergő Tóth ${ }^{4}\left(\mathbb{D}\right.$, Pongsiri Jaikumpun ${ }^{1}{ }^{\circledR}$, Ilona Gróf ${ }^{5}$,

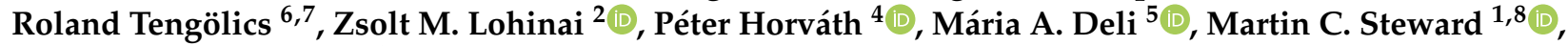 \\ Orsolya Dobay $^{3}$ and Ákos Zsembery ${ }^{1, *}$
}

1 Department of Oral Biology, Semmelweis University, H-1089 Budapest, Hungary; ksd13rsk@gmail.com (K.R.); pongsirij@nu.ac.th (P.J.); martin.steward@me.com (M.C.S.)

2 Department of Conservative Dentistry, Semmelweis University, H-1085 Budapest, Hungary; lohinai.zsolt@dent.semmelweis-univ.hu

3 Institute of Medical Microbiology, Faculty of Medicine, Semmelweis University, H-1089 Budapest, Hungary; stercz.balazs@med.semmelweis-univ.hu (B.S.); dobay.orsolya@med.semmelweis-univ.hu (O.D.)

4 Department of Pharmaceutical Chemistry, Semmelweis University, H-1092 Budapest, Hungary; toth.gergo@pharma.semmelweis-univ.hu (G.T.); horvath.peter@pharma.semmelweis-univ.hu (P.H.)

5 Institute of Biophysics, Biological Research Centre, H-6726 Szeged, Hungary; grof.ilona@brc.hu (I.G.); deli.maria@brc.hu (M.A.D.)

6 Institute of Biochemistry, Biological Research Centre, H-6726 Szeged, Hungary; tengolics.roland@brc.hu

7 HCEMM-BRC Metabolic Systems Biology Laboratory, H-6726 Szeged, Hungary

8 School of Medical Sciences, University of Manchester, Manchester M13 9PL, UK

check for updates

Citation: Ruksakiet, K.; Stercz, B.; Tóth, G.; Jaikumpun, P.; Gróf, I.; Tengölics, R.; Lohinai, Z.M.; Horváth, P.; Deli, M.A.; Steward, M.C.; et al. Bicarbonate Evokes Reciprocal Changes in Intracellular Cyclic di-GMP and Cyclic AMP Levels in Pseudomonas aeruginosa. Biology 2021, 10, 519. https://doi.org/10.3390/ biology10060519

Academic Editor: Wito Richter

Received: 17 May 2021

Accepted: 8 June 2021

Published: 10 June 2021

Publisher's Note: MDPI stays neutral with regard to jurisdictional claims in published maps and institutional affiliations.

Copyright: (c) 2021 by the authors. Licensee MDPI, Basel, Switzerland. This article is an open access article distributed under the terms and conditions of the Creative Commons Attribution (CC BY) license (https:// creativecommons.org/licenses/by/ $4.0 /)$.
* Correspondence: zsembery.akos@dent.semmelweis-univ.hu

Simple Summary: Cystic fibrosis (CF) is the most common lethal hereditary disease in Caucasians, causing mainly respiratory and gastrointestinal symptoms. In $\mathrm{CF}$, mutations in the gene encoding an epithelial anion channel cause impaired bicarbonate secretion, which contributes to the formation of thick mucus in the airways. Together with reduced mucociliary clearance, this habitat is ideal for bacterial growth. Biofilm formation contributes to persistent infections and inflammation, as well as higher resistance to antibiotics, and therefore represents one of the major challenges for CF therapy. It is also known that second messenger molecules play pivotal roles in the regulation of bacterial lifestyle. Furthermore, the activities of the enzymes that synthesize or break down these second messengers are sensitive to external $\mathrm{pH}$ and bicarbonate. Therefore, we hypothesized that $\mathrm{pH}$ and/or bicarbonate could influence bacterial behavior. In this work, we have shown that bicarbonate per se regulates the concentrations of bacterial second messengers and inhibits biofilm formation. These results suggest that bicarbonate could be used as a supportive treatment in CF and possibly in other respiratory diseases associated with chronic bacterial infections and viscous mucus production.

Abstract: The formation of Pseudomonas aeruginosa biofilms in cystic fibrosis (CF) is one of the most common causes of morbidity and mortality in CF patients. Cyclic di-GMP and cyclic AMP are second messengers regulating the bacterial lifestyle transition in response to environmental signals. We aimed to investigate the effects of extracellular $\mathrm{pH}$ and bicarbonate on intracellular c-di-GMP and cAMP levels, and on biofilm formation. P. aeruginosa was inoculated in a brain-heart infusion medium supplemented with 25 and $50 \mathrm{mM} \mathrm{NaCl}$ in ambient air (pH adjusted to 7.4 and 7.7 respectively), or with 25 and $50 \mathrm{mM} \mathrm{NaHCO}_{3}$ in $5 \% \mathrm{CO}_{2}$ (pH 7.4 and 7.7). After $16 \mathrm{~h}$ incubation, c-di-GMP and cAMP were extracted and their concentrations determined. Biofilm formation was investigated using an xCelligence real-time cell analyzer and by crystal violet assay. Our results show that $\mathrm{HCO}_{3}{ }^{-}$exposure decreased c-di-GMP and increased cAMP levels in a dose-dependent manner. Biofilm formation was also reduced after $48 \mathrm{~h}$ exposure to $\mathrm{HCO}_{3}{ }^{-}$. The reciprocal changes in second messenger concentrations were not influenced by changes in medium $\mathrm{pH}$ or osmolality. These findings indicate that $\mathrm{HCO}_{3}{ }^{-}$per se modulates the levels of c-di-GMP and cAMP, thereby inhibiting biofilm formation and promoting the planktonic lifestyle of the bacteria. 
Keywords: c-di-GMP; cAMP; P. aeruginosa; bicarbonate; $\mathrm{pH}$; biofilm; cystic fibrosis; chronic infection

\section{Introduction}

Pseudomonas aeruginosa is one of the most prevalent pathogens causing nosocomial infections in several organs, particularly chronic respiratory diseases [1]. Its pathogenicity is associated with biofilm formation, expression of various virulence factors, such as type II and III secretion systems (T2SS and T3SS) and type IV pili, and reduced susceptibility to antibiotics, all of which largely depend on altered intracellular second messenger levels [2-5]. Bis- $\left(3^{\prime}-5^{\prime}\right)$-cyclic dimeric guanosine monophosphate (c-di-GMP) is a bacterial second messenger that mediates the lifestyle transition from motility to sessility $[2,6]$. In $P$. aeruginosa, c-di-GMP also regulates other biological processes, including virulence, quorum sensing, and cross-talk with other second messengers such as $3^{\prime}, 5^{\prime}$-cyclic adenosine monophosphate (cAMP) and hyperphosphorylated guanosine derivatives (p)ppGpp [4,7]. Intracellular c-di-GMP levels are elevated by activation of diguanylate cyclases (DGCs) and reduced by stimulation of c-di-GMP phosphodiesterases (PDEs) [2,6]. Cyclic AMP was first described in eukaryotic cells but subsequently found also in bacteria [3]. It is responsible for modulating catabolic metabolism, virulence factor expression, and lifestyle transitions. Intracellular cAMP levels are regulated by the concerted action of adenylate cyclases (ACs) such as CyaA, CyaB or ExoY, and cAMP PDEs [3]. The activity of enzymes regulating c-di-GMP and cAMP concentrations can be influenced by extracellular signaling molecules, which may act at transcriptional, translational and/or post-translational levels [2,3]. For example, nitric oxide (NO) induces biofilm dispersion by altering c-di-GMP PDE activity [8]. Furthermore, as a host-activated AC toxin, cytosolic $\mathrm{Ca}^{2+}$ concentrations can determine T3SS activity by controlling cAMP concentration [3]. Our previous work also indicates that alkaline $\mathrm{pH}$ and $\mathrm{HCO}_{3}{ }^{-}$increase intracellular cAMP levels and reduce biofilm formation [9].

Bicarbonate ions possess antibacterial properties that enhance the efficacy of both antimicrobial peptides [10] and synthetic antibiotics [11]. It has also been shown that $\mathrm{NaHCO}_{3}$ can disrupt mature dental biofilms [12]. Recently, we have reported that $\mathrm{HCO}_{3}{ }^{-}$ is bacteriostatic in media modified to mimic cystic fibrosis (CF) sputum [13]. $\mathrm{HCO}_{3}{ }^{-}$is useful not only in medicine, but also in industry as a disinfectant [14] or antiviral agent [15]. In addition, $\mathrm{HCO}_{3}{ }^{-}$plays a pivotal role in epithelial fluid secretion and calcium chelation, determining the tertiary structure of secreted mucins [16] in several organs such as the airways, gastrointestinal, and reproductive tracts $[17,18] . \mathrm{HCO}_{3}{ }^{-}$secretion is impaired in $\mathrm{CF}$ due to mutations in the gene encoding the cystic fibrosis transmembrane conductance regulator (CFTR) protein [16]. Hyposecretion of $\mathrm{HCO}_{3}{ }^{-}$, in parallel with hyperabsorption of $\mathrm{Na}^{+}$, leads to airway surface liquid (ASL) dehydration. $\mathrm{As}^{\mathrm{HCO}_{3}}{ }^{-}$typically maintains $\mathrm{pH}$ balance in the airways, defective CFTR function also causes increased acidity of the ASL and it eventually weakens immune-cell function. Due to low $\mathrm{HCO}_{3}{ }^{-}$levels, a thick mucus is accumulated, leading to airway blockage and decreased mucociliary clearance (MCC) $[19,20]$. These conditions provide a favorable habitat for bacterial colonization [20].

$P$. aeruginosa is one of the most common bacteria colonizing the adult CF lung. In chronic infections, P. aeruginosa forms a biofilm enclosed in a self-produced extracellular matrix which provides protection against the host's immune response and against natural and synthetic antibiotics, leading to the high morbidity and mortality of CF patients [21]. Given the potential therapeutic value of $\mathrm{HCO}_{3}{ }^{-}$, it is encouraging to note that Gomez et al., have demonstrated that administration of hypertonic $\mathrm{NaHCO}_{3}$ aerosols is safe and well-tolerated by CF patients [22].

Interplay between c-di-GMP and cAMP has been shown to control the lifestyle transition and virulence of $P$. aeruginosa $[5,23]$. Therefore, targeting these second messengers might be an effective therapeutic approach to combat bacterial colonization in CF airways. Since many small extracellular molecules, such as glycosylated triterpenoid saponin, 
sodium orthovanadate, and phosphoserine, as well as $\mathrm{HCO}_{3}{ }^{-} / \mathrm{CO}_{2}$, are known to modulate enzymes associated with second messenger production and degradation [24-27], we hypothesized that extracellular $\mathrm{HCO}_{3}{ }^{-}$could also modulate the cAMP and/or c-diGMP levels influencing biofilm formation. Therefore, our aim was to investigate the effects of $\mathrm{HCO}_{3}{ }^{-}$on second messengers and biofilm formation in P. aeruginosa. Data presented here indicate that $\mathrm{HCO}_{3}{ }^{-}$causes reciprocal changes in cAMP and c-di-GMP levels as well as inhibiting biofilm formation.

\section{Materials and Methods}

\subsection{Growth Conditions and Bacterial Strains}

Brain-heart infusion (BHI) medium (Mast Group Ltd., Merseyside, UK) was supplemented with either $\mathrm{NaHCO}_{3}$ or $\mathrm{NaCl}$ as follows: 1) BHI alone pH 7.4; 2) BHI $+25 \mathrm{mM}$ $\mathrm{NaCl} \mathrm{pH} 7.4$; 3) $\mathrm{BHI}+25 \mathrm{mM} \mathrm{NaHCO}_{3} \mathrm{pH} 7.4$; 4) BHI + $50 \mathrm{mM} \mathrm{NaCl}, \mathrm{pH}$ 7.7; and 5) $\mathrm{BHI}+50 \mathrm{mM} \mathrm{NaHCO}_{3} \mathrm{pH}$ 7.7. The $\mathrm{pH}$ of $\mathrm{BHI}$ and $\mathrm{BHI}$ media supplemented with $\mathrm{NaCl}$ was adjusted with $\mathrm{NaOH}$ or $\mathrm{HCl}$, whereas $\mathrm{BHI}$ medium supplemented with $\mathrm{NaHCO}_{3}$ was equilibrated with $5 \% \mathrm{CO}_{2}$ to obtain the $\mathrm{pH}$ values indicated above. Single colonies of $P$. aeruginosa, ATCC 27853 and 17808 (clinical isolate), were cultured overnight.

The optical density at $595 \mathrm{~nm}\left(\mathrm{OD}_{595}\right)$ of the overnight cultures was measured with a PR2100 microplate reader (Bio-Rad Laboratories, Hercules, CA, USA) and the cultures were then diluted to $\mathrm{OD}_{595}=0.4$. They were inoculated in triplicate in $20 \mathrm{~mL}$ of designated medium for each condition. Cultures in $\mathrm{BHI}$ medium with added $\mathrm{NaCl}$ were incubated at $37^{\circ} \mathrm{C}$ in ambient air, while the $\mathrm{NaHCO}_{3}$ groups were incubated in the presence of $5 \% \mathrm{CO}_{2}$.

\subsection{Extraction of $c-d i-G M P$ and $c A M P$}

The extraction method was modified from that used by Petrova and Sauer (2017) [28]. Briefly, after $16 \mathrm{~h}$ incubation, the $\mathrm{OD}_{595}$ values of the bacterial cultures were determined. To obtain the same number of bacteria for extraction from each culture, a sample volume was calculated, equivalent to $20 \mathrm{~mL}$ of $\mathrm{OD}_{595}=0.2$. For example, if the $\mathrm{OD}_{595}$ was 0.4, the sample volume would be $10 \mathrm{~mL}$. Bacterial cells were harvested by centrifugation at $5000 \times g$ rpm for $10 \mathrm{~min}$, and the media were discarded. They were then washed three times with $1 \mathrm{~mL}$ ice-cold PBS. The cell pellets were resuspended in $100 \mu \mathrm{L}$ ice-cold PBS and the extraction of cyclic nucleotides was initiated by incubation at $100{ }^{\circ} \mathrm{C}$ for $5 \mathrm{~min}$, followed by the addition of $186 \mu \mathrm{L}$ ice-cold absolute ethanol. The resulting solution was centrifuged and the supernatant, containing the extracted cyclic nucleotides, was removed and kept on ice. The extraction with heat and ethanol was repeated twice from the retained cell pellets. The supernatants from the three extractions were then pooled together in one tube and dried in a centrifugal evaporator (Labconco Centrivap Concentrator, Kansas City, MO, USA). The remaining cell pellets were kept for protein measurement. They were resuspended in $1 \mathrm{~mL}$ of $0.1 \mathrm{M} \mathrm{NaOH}$, incubated at $95^{\circ} \mathrm{C}$ for $15 \mathrm{~min}$, and then sonicated on ice as previously described [29]. The protein measurement was carried out using a Quant-iT ${ }^{\mathrm{TM}}$ protein assay (Thermo Fisher Scientific, Waltham, MA, USA), according to the manufacturer's instructions. Finally, total cellular protein content was used to normalize the c-di-GMP and cAMP levels obtained from the quantification. Three independent bacterial cultures were performed in all cases.

\subsection{Quantification of $c-d i-G M P$ and $c A M P$}

The extracted c-di-GMP and cAMP were detected by high-performance liquid chromatography with mass spectrometric detection (HPLC-MS) according to a modified protocol from the above-mentioned study [28]. HPLC analysis was performed using an Agilent 1260 Infinity LC system in conjunction with an Agilent 6460 triple-quadrupole mass spectrometer (Waldbroon, Germany). Chromatography was carried out using an Agilent Eclipse Plus C18 column $(4.6 \times 100 \mathrm{~mm}, 3.5 \mu \mathrm{m})$. For the separation, the following gradient elution program was used, mixing Solvent $\mathrm{A}(10 \mathrm{mM}$ ammonium acetate in water) and solvent B (10 mM ammonium acetate in methanol): 0 to $9 \mathrm{~min} \mathrm{1 \%} \mathrm{B,} 9$ to $14 \mathrm{~min}$ 
$15 \% \mathrm{~B}, 14$ to $19 \mathrm{~min} 25 \% \mathrm{~B}, 19$ to $26 \mathrm{~min} 90 \% \mathrm{~B}$ and 26 to $30 \mathrm{~min} 1 \% \mathrm{~B}$. The flow rate was $0.3 \mathrm{~mL} / \mathrm{min}$. Standards for c-di-GMP and cAMP quantification were purchased from Sigma Aldrich (St. Louis, MO, USA). The mass spectrometer was operated in conjunction with a Jet Stream electrospray ion source in positive ion mode and was set to monitor in selective ion monitoring (SIM) mode. The following MS parameters were used: fragmentor voltage $130 \mathrm{~V}$; dwell time $200 \mathrm{~ms}$; delta EMV $10 \mathrm{~V}$. Flow and temperature of the drying gas $\left(\mathrm{N}_{2}\right)$ in the ion source were $10 \mathrm{~L} / \mathrm{min}$ and $300{ }^{\circ} \mathrm{C}$, respectively; the pressure of the nebulizer gas $\left(\mathrm{N}_{2}\right), 45$ psi; capillary voltage, $3000 \mathrm{~V}$; sheath gas flow and temperature, $10 \mathrm{~L} / \mathrm{min}$ and $300{ }^{\circ} \mathrm{C}$. Mass spectra were processed using Agilent MassHunter B.04.00 software. The dried supernatant samples from the bacterial extracts were resolved in nanopure water, then vortexed and centrifuged to remove insoluble particles. The samples were carefully filtered with a $2 \mu \mathrm{m}$ filter into a new microcentrifuge tube. We analyzed the final volume (20 $\mu \mathrm{L}$ per sample) using HPLC-MS.

\subsection{Real-Time Biofilm Monitoring}

For the biofilm experiments, BHI medium was supplemented with $1 \%$ glucose and sterilized by filtration. BHI medium supplemented with either 25 or $50 \mathrm{mM} \mathrm{NaHCO} 3$ was incubated at $5 \% \mathrm{CO}_{2}$ and prepared as described above. The $\mathrm{pH}$ of media supplemented with $\mathrm{NaCl}(25$ or $50 \mathrm{mM}$ ) was adjusted with $\mathrm{NaOH}$ to $\mathrm{pH} 8.0$ or $\mathrm{pH} 8.4$, respectively. We set the $\mathrm{pH}$ at $0.6-0.7$ units higher than the desired values because the experiments were carried out in the presence of $5 \% \mathrm{CO}_{2}$, which reduced the $\mathrm{pH}$ during the measurements. Similarly, the pH of BHI medium alone was adjusted to either 8.0 or 8.4 and used as the control medium.

96-well E-plates were used in conjunction with a real-time cell analyzer (RTCA) (xCELLigence, ACEA Bioscience Inc., San Diego, CA, USA). After overnight culture, the ODs were determined and standardized to $10^{9} \mathrm{CFU} / \mathrm{mL}$ by dilution with $\mathrm{BHI}$ medium at $\mathrm{pH} 7.4$ containing $1 \%$ glucose. Bacterial suspensions were obtained, equivalent to $20 \mu \mathrm{L}$ of $10^{8} \mathrm{CFU} / \mathrm{mL}$, and inoculated in $180 \mu \mathrm{L}$ of the designated medium, resulting in final volumes of $200 \mu \mathrm{L}$ per well. Five replicate wells were prepared for each condition. The E-plate was incubated at $37^{\circ} \mathrm{C}$ with $5 \% \mathrm{CO}_{2}$ for $48 \mathrm{~h}$. After bacterial inoculation, the RTCA impedance signal was recorded every $10 \mathrm{~min}$ for $48 \mathrm{~h}$. The recorded signals obtained at 6 , 12,24 and $48 \mathrm{~h}$ were converted by the xCELLigence software to delta cell indices $(\Delta \mathrm{CI})$.

\subsection{Biofilm Assessment Using Crystal Violet Assay}

P. aeruginosa, both ATCC 27853 and 17808 (clinical isolate), were grown in 96-well polystyrene flat-bottom microtiter plates (Eppendorf ${ }^{\circledR}, 0030730119$, Hamburg, Germany). BHI media supplemented with 25 and $50 \mathrm{mM} \mathrm{NaHCO}_{3}$ were prepared as described above. The $\mathrm{pH}$ values of the $\mathrm{BHI}$ media supplemented with $\mathrm{NaCl}$ were adjusted in the same way as for the impedance-based RTCA method. Briefly, $20 \mu \mathrm{L}$ samples of the overnight cultures diluted to $\mathrm{OD}_{595}=0.1$ were inoculated in wells containing $180 \mu \mathrm{L}$ designated medium in 5 parallels for each group. Sterile distilled water $(200 \mu \mathrm{L})$ was added to each empty well as previously recommended [30,31]. The plate was incubated for $48 \mathrm{~h}$ at $37{ }^{\circ} \mathrm{C}$ in $5 \% \mathrm{CO}_{2}$. $180 \mu \mathrm{L}$ of the supernatant was carefully aspirated from each well, which was then washed by adding $200 \mu \mathrm{L}$ PBS and discarding the supernatant. This washing step was repeated twice. The plate was then dried at $42.5^{\circ} \mathrm{C}$ for $90 \mathrm{~min} .200 \mu \mathrm{L}$ of $0.1 \%$ crystal violet was added to each well to stain the biofilm. After $15 \mathrm{~min}$, the excess crystal violet was removed and the well washed with distilled water. The plate was dried at room temperature for $30 \mathrm{~min}$. Finally, $200 \mu \mathrm{L}$ of $30 \%$ acetic acid was added to each well for $15 \mathrm{~min}$, and $125 \mu \mathrm{L}$ of the dissolved crystal violet was transferred to a new plate for $\mathrm{OD}_{595}$ measurement. Three independent biological cultures were performed.

\subsection{Statistical Analysis}

Normalized c-di-GMP and cAMP concentrations were calculated by Microsoft Excel for Office 365 using a previously described formula [28]. Data are presented as 
means \pm standard error (SEM). One-way ANOVA was used to analyze the second-messenger results, whereas a two-way ANOVA, followed by a multiple comparison test, was used for the biofilm results. GraphPad Prism version 8.0.0 was used for statistical analysis. Significance was accepted at $p<0.05$.

\section{Results}

3.1. Sodium Bicarbonate Modulates Both c-di-GMP and cAMP Levels in P. aeruginosa

\subsubsection{Sodium Bicarbonate Decreases Intracellular c-di-GMP Levels}

In order to test the effects of $\mathrm{HCO}_{3}{ }^{-}$on intracellular c-di-GMP levels in P. aeruginosa (ATCC 27853 and clinical isolate 17808), we incubated the bacteria for $16 \mathrm{~h}$ in BHI medium supplemented with either $\mathrm{NaHCO}_{3}(25$ or $50 \mathrm{mM})$ or $\mathrm{NaCl}(25$ or $50 \mathrm{mM})$. In P. aeruginosa ATCC 27853, c-di-GMP levels were significantly reduced in media containing both 25 and $50 \mathrm{mM} \mathrm{NaHCO}_{3}$ compared to media containing 25 and $50 \mathrm{mM} \mathrm{NaCl}$, respectively (Figure 1a). In P. aeruginosa clinical isolate 17808, $50 \mathrm{mM} \mathrm{NaHCO}_{3}$ decreased c-di-GMP concentrations significantly, but $25 \mathrm{mM}$ did not (Figure 1c). These data show that the $\mathrm{NaHCO}_{3}$-induced decreases in c-di-GMP levels were dose-dependent in both $P$. aeruginosa ATCC 27853 and clinical isolate 17,808 (Figure 1a,c). Neither $25 \mathrm{mM} \mathrm{NaCl}$ (pH 7.4) nor $50 \mathrm{mM} \mathrm{NaCl}$ (pH 7.7) induced changes in c-di-GMP concentrations, suggesting that alterations in $\mathrm{pH}$ or osmolarity did not play a role in these inhibitory effects. Thus, our results indicate that it is $\mathrm{HCO}_{3}{ }^{-}$per se that decreases the intracellular c-di-GMP concentrations.

\subsubsection{Sodium Bicarbonate Increases Intracellular cAMP Levels}

In parallel with the c-di-GMP measurements, we also investigated the changes in intracellular cAMP concentration induced by $\mathrm{NaHCO}_{3}$. As shown in Figure $1 \mathrm{~b}$ ( $P$. aeruginosa ATCC 27853) and Figure 1d (P. aeruginosa clinical isolate 17808), both 25 and $50 \mathrm{mM}$ $\mathrm{NaHCO}_{3}$ elevated cAMP levels when compared to treatments with equimolar concentrations of $\mathrm{NaCl}$ at the same $\mathrm{pH}$ values. Supplementation of $\mathrm{BHI}$ medium with 25 or $50 \mathrm{mM} \mathrm{NaCl}$ caused no significant change in cAMP concentration, suggesting that the $\mathrm{HCO}_{3}{ }^{-}$-induced effects were not due to the accompanying osmolarity or $\mathrm{pH}$ changes (Figure 1b,d).

\subsection{Sodium Bicarbonate Inhibits P. aeruginosa Biofilm Formation}

\subsubsection{Effects of Sodium Bicarbonate Assessed by Real-Time Cell Analysis (RTCA)}

The ability of $P$. aeruginosa to form biofilms was assessed by RTCA and quantified as the delta cell index $(\Delta C \mathrm{C})$, a parameter, which increases with biofilm formation. Although biofilm formation generally requires at least $24 \mathrm{~h}$, here we also present data following 6 and $12 \mathrm{~h}$ incubation. Interestingly, in the clinical isolate, $\Delta \mathrm{CI}$ increased dramatically at $48 \mathrm{~h}$, indicating particularly strong biofilm formation (Figure $2 \mathrm{~b}$ ).

The effects of $\mathrm{HCO}_{3}{ }^{-}$were investigated in $\mathrm{BHI}$ medium supplemented with either $\mathrm{NaHCO}_{3}(25$ or $50 \mathrm{mM}$ ) or $\mathrm{NaCl}(25$ or $50 \mathrm{mM}$ ) as a control (Figure 2). Regardless of whether the $\mathrm{BHI}$ medium was supplemented with $\mathrm{NaHCO}_{3}$ or $\mathrm{NaCl}, \triangle \mathrm{CI}$ increased with incubation time in both the ATCC strain and the clinical isolate. As with the BHI medium alone, $\Delta C I$ increased dramatically in the clinical isolate incubated in BHI medium supplemented with 25 or $50 \mathrm{mM} \mathrm{NaCl}$ for $48 \mathrm{~h}$ (Figure $2 \mathrm{~b}, \mathrm{~d}$ ). However, both 25 and $50 \mathrm{mM} \mathrm{NaHCO}$ greatly reduced $\Delta \mathrm{CI}$, compared with the same concentration of $\mathrm{NaCl}$, following $48 \mathrm{~h}$ incubation. This indicates an inhibition of biofilm formation that was particularly pronounced in the clinical isolate culture (Figure $2 \mathrm{~b}, \mathrm{~d}$ ). 


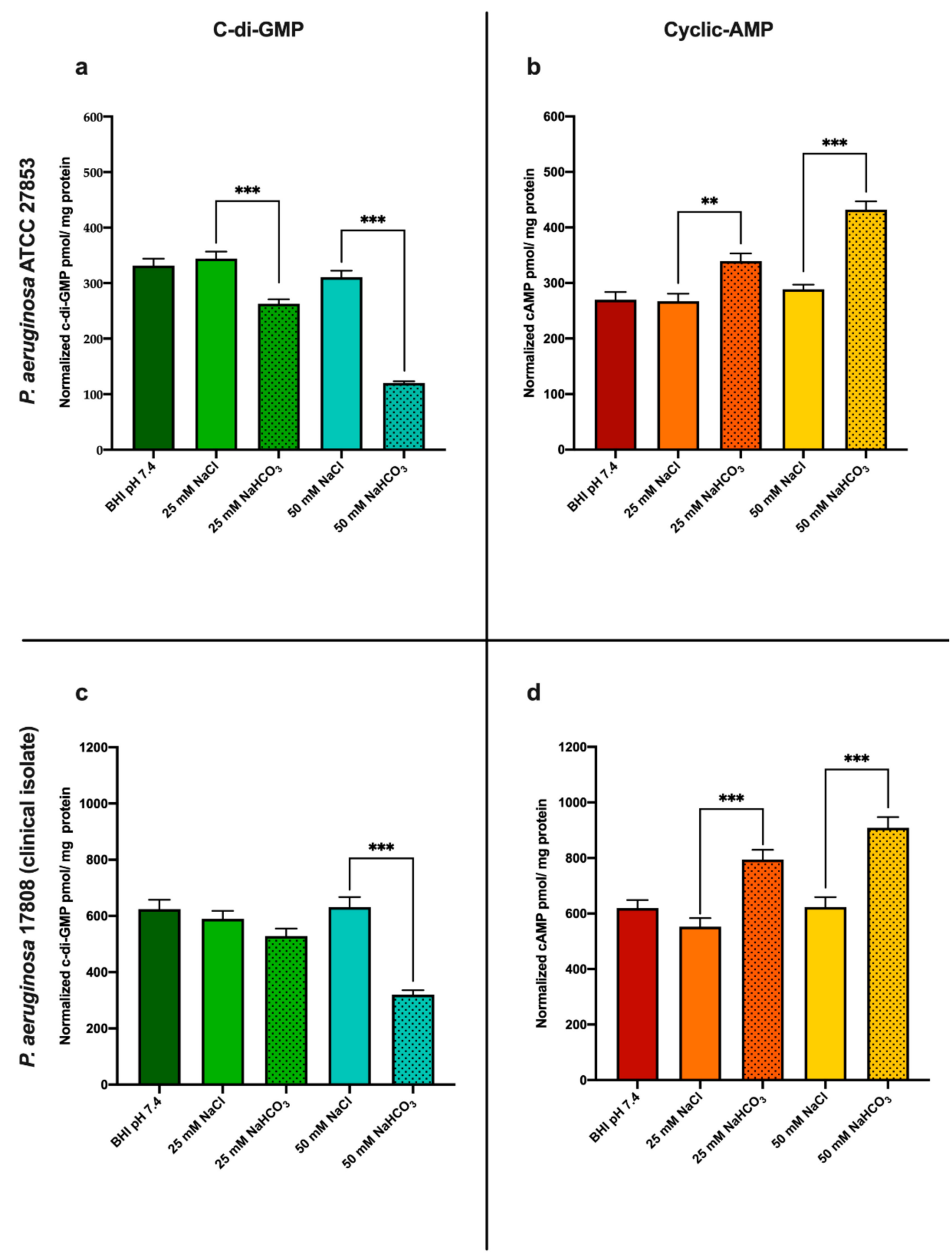

Figure 1. Intracellular second messenger levels after $16 \mathrm{~h}$ incubation: (a) c-di-GMP levels and (b) cAMP levels in P. aeruginosa ATCC 27853; (c) c-di-GMP levels, and (d) cAMP levels in P. aeruginosa 17808 (clinical isolate). Values are presented as means \pm SEM of the c-di-GMP or cAMP levels normalized to cellular protein from 3 independent experiments. One-way ANOVA and Tukey's multiple comparisons test: ${ }^{* *} p<0.01$ and ${ }^{* *} p<0.001$ when comparing cells in BHI medium supplemented with $\mathrm{NaHCO}_{3}$ and cells in $\mathrm{BHI}$ medium supplemented with an equal concentration of $\mathrm{NaCl}$ at the same $\mathrm{pH}$. 


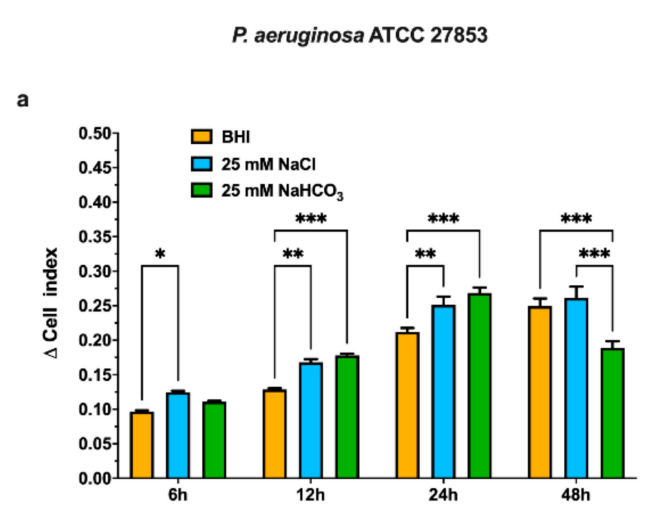

c

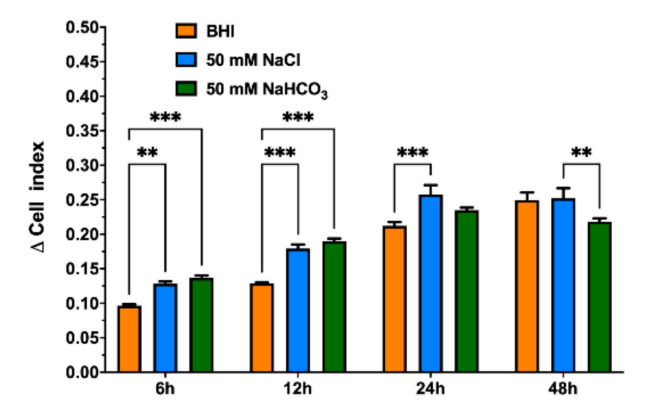

$P$. aeruginosa 17808 (clinical isolate)

b

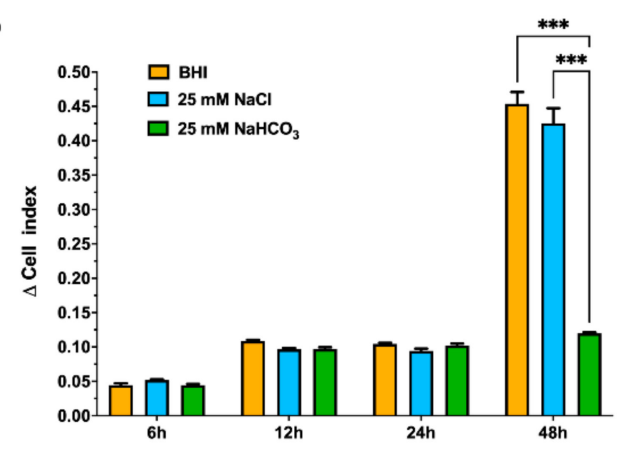

d

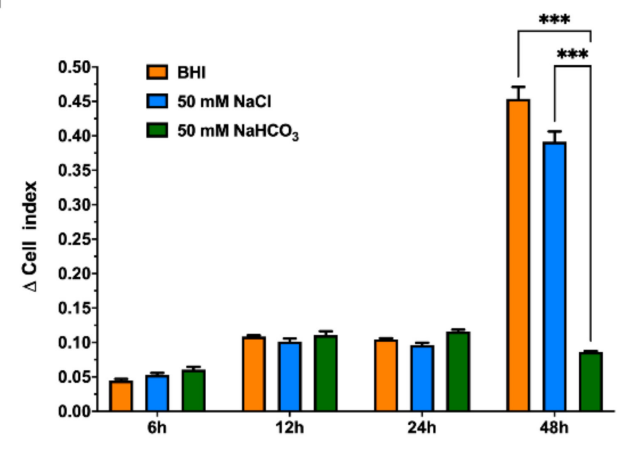

Figure 2. Biofilm formation by P. aeruginosa ATCC 27853 (a,c) and P. aeruginosa 17808 (clinical isolate) (b,d) in media supplemented with $25 \mathrm{mM}(\mathbf{a}, \mathbf{b})$ or $50 \mathrm{mM}(\mathbf{c}, \mathbf{d}) \mathrm{NaCl}_{\text {or }} \mathrm{NaHCO}_{3}$ using real-time biofilm monitoring (RTCA) at specified time points. Values are presented as means of $\Delta$ cell index \pm SEM from $4-5$ parallel measurements. Two-way ANOVA and Tukey's multiple comparisons test: ${ }^{*} p<0.05,{ }^{* *} p<0.01$ and ${ }^{* * *} p<0.001$ when comparing pure BHI medium, BHI medium supplemented with $\mathrm{NaHCO}_{3}$, and $\mathrm{BHI}$ medium supplemented with an equal concentration of $\mathrm{NaCl}$.

\subsubsection{Effects of Sodium Bicarbonate Assessed by Crystal Violet Assay}

As a further test of the effects of $\mathrm{NaHCO}_{3}$ on biofilm formation, we used the crystal violet assay after $48 \mathrm{~h}$ incubation (Figure 3). In P. aeruginosa ATCC 27853, neither $25 \mathrm{mM}$ nor $50 \mathrm{mM} \mathrm{NaHCO}_{3}$ decreased biofilm formation as judged by this assay (Figure 3a). However, $50 \mathrm{mM} \mathrm{NaHCO}_{3}$ did significantly reduce biofilm formation by P. aeruginosa 17808 (clinical isolate) (Figure $3 b$ ). Interestingly $25 \mathrm{mM} \mathrm{NaCl}$ increased P. aeruginosa 17808 (clinical isolate) biofilm formation (Figure $3 \mathrm{~b}$ ). These data also suggest that changes in osmolarity or $\mathrm{pH}$ are not responsible for the inhibitory effect of $\mathrm{NaHCO}_{3}$. 

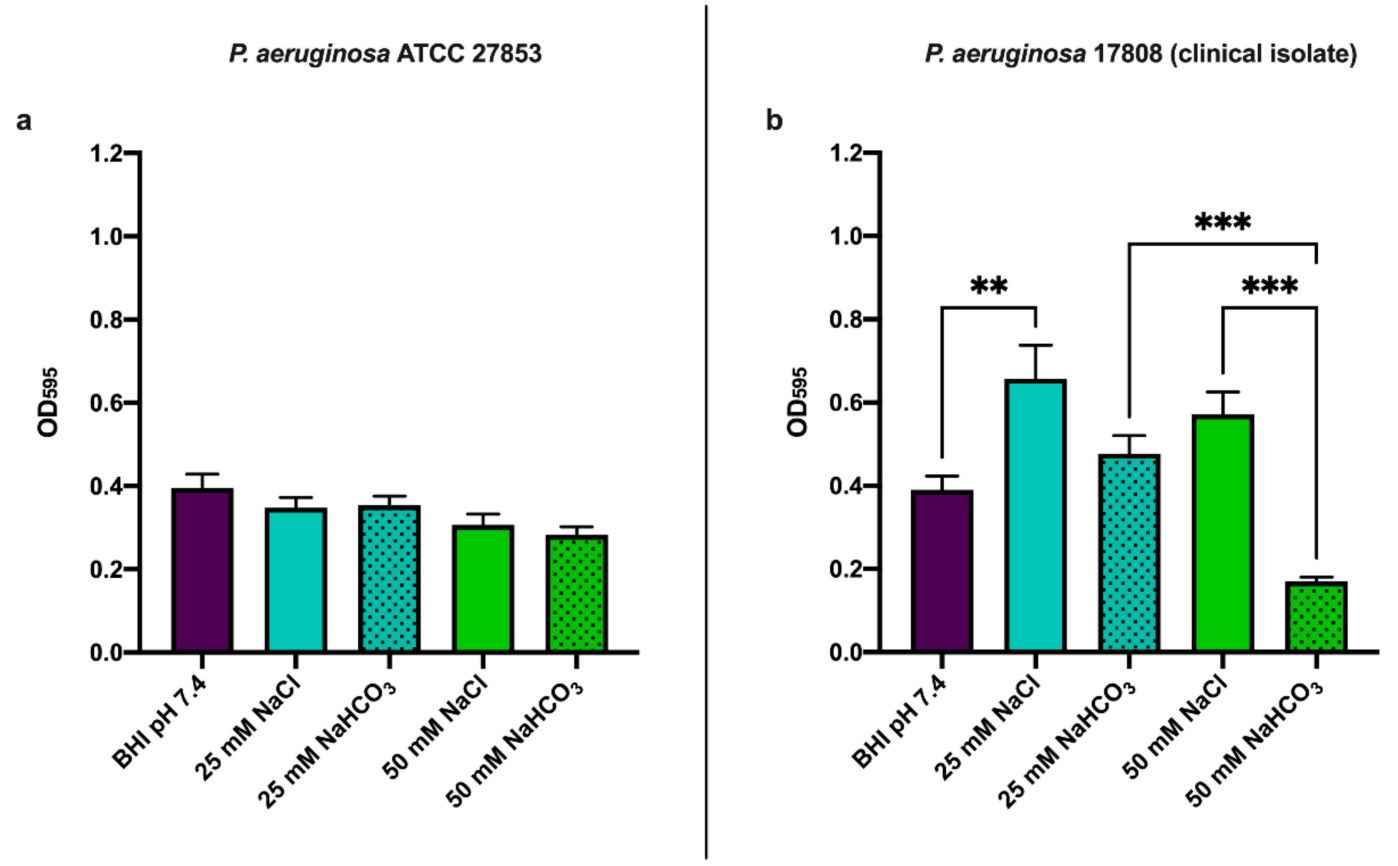

Figure 3. Biofilm formation at $48 \mathrm{~h}$ using crystal violet assay: (a) P. aeruginosa ATCC 27853 and (b) P. aeruginosa 17808 (clinical isolate). Values are presented as means of $\mathrm{OD}_{595} \pm \mathrm{SEM}$ from 3 independent experiments. One-way ANOVA and Tukey's multiple comparisons test: ${ }^{* *} p<0.01$ and ${ }^{* * *} p<0.001$ when comparing $\mathrm{BHI}$ medium supplemented with $\mathrm{NaHCO}_{3}$ and $\mathrm{BHI}$ medium supplemented with the same concentration of $\mathrm{NaCl}$.

\section{Discussion}

Acid-base transporters regulate ASL $\mathrm{pH}$, which is essential to the homeostasis of the respiratory system. CFTR plays a pivotal role in $\mathrm{HCO}_{3}{ }^{-}$secretion across airway epithelia, and impaired $\mathrm{HCO}_{3}{ }^{-}$secretion in $\mathrm{CF}$ leads to an acidic luminal $\mathrm{pH}$ that provides favorable conditions for $P$. aeruginosa colonization [16,21]. In P. aeruginosa, enzymes regulating the levels of intracellular second messengers (c-di-GMP and cAMP) are known to be sensitive to changes in environmental $\mathrm{HCO}_{3}{ }^{-}$concentrations. Since both c-di-GMP and cAMP may influence biofilm formation, alterations in their concentrations could play an important role in chronic $\mathrm{CF}$ airway infections $[2,3,21]$. The main findings of the current study demonstrate that $\mathrm{HCO}_{3}{ }^{-}$administration evokes reciprocal changes in c-di-GMP and cAMP concentrations in P. aeruginosa, which result in inhibition of biofilm formation.

Bacteria can exist either as free-floating planktonic cells or as sessile colonies forming biofilms. It has been demonstrated that high intracellular levels of c-di-GMP promote biofilm formation, whereas lower concentrations induce the planktonic lifestyle [2,6,32]. Our results indicate that both 25 and $50 \mathrm{mM} \mathrm{NaHCO}_{3}$ reduce c-di-GMP levels in the ATCC strain of $P$. aeruginosa. In the clinical isolate strain, $50 \mathrm{mM}$ but not $25 \mathrm{mM} \mathrm{NaHCO}_{3}$ reduced c-di-GMP levels, suggesting a different sensitivity of these bacteria to external $\mathrm{HCO}_{3}{ }^{-}$ (Figure 1a,c).

In general, modulation of intracellular c-di-GMP concentrations may be explained either by activation of PDEs and/or inhibition of DGCs. For example, Koestler and Waters showed that, in Vibrio cholerae, $\mathrm{HCO}_{3}{ }^{-}$and bile acids can suppress DGCs activity and simultaneously stimulate PDEs, both leading to decreased c-di-GMP levels [33]. Clearly, further studies are needed to identify the molecular pathways by which $\mathrm{HCO}_{3}{ }^{-}$modulates c-di-GMP levels in P. aeruginosa.

P. aeruginosa isolates from CF airways and/or sputum are typically derived from the same strain but show extensive phenotypic heterogeneity [34]. Some of these variants develop an increased ability to form biofilms and are frequently resistant to antibiotics. 
These are called small colony variants (SCVs) [35]. The underlying mechanisms responsible for the generation of SCVs are still unclear, but the final common pathway seems to be an increase in bacterial c-di-GMP concentrations [36,37]. SCVs also produce large amounts of exopolysaccharides that play a crucial role in the development of antibiotic resistance [35,38]. Elevated c-di-GMP has been recognized as essential for promoting the SCV phenotype change and is thought to occur as a result of overexpression and/or activation of DGCs such as WspR or YfiN (TbpB) [2].

Our findings clearly support the idea that inhalation of $\mathrm{NaHCO}_{3}$-containing aerosols might influence the P. aeruginosa phenotype change in CF. Either by reducing DGC activity or increasing PDE activity, $\mathrm{HCO}_{3}{ }^{-}$exposure could effectively lower bacterial c-di-GMP levels and reduce the likelihood of biofilm formation in the airways.

Aside from c-di-GMP-mediated biofilm formation, cAMP may also participate in this process. We therefore also investigated the effects of $\mathrm{HCO}_{3}{ }^{-}$on bacterial cAMP levels. In contrast to the effects on c-di-GMP, $\mathrm{HCO}_{3}{ }^{-}$increased cAMP concentrations in a dose-dependent manner. Our observations are in line with previous studies showing similar results in a range of 5 to $25 \mathrm{mM} \mathrm{NaHCO}_{3}$, which activated $\mathrm{CyaB}$ and increased intracellular cAMP levels [27]. Furthermore, $\mathrm{HCO}_{3}{ }^{-}$can also stimulate soluble $\mathrm{AC}$ in both bacterial and mammalian cells-another pathway leading to increased intracellular cAMP concentrations $[39,40]$. Although we cannot exclude the possibility that PDE activities are also regulated by $\mathrm{HCO}_{3}{ }^{-}$, no current evidence is available to support this hypothesis.

By assessing changes in bacterial c-di-GMP and cAMP levels concurrently, we found that $\mathrm{HCO}_{3}{ }^{-}$regulates c-di-GMP and cAMP levels in a reciprocal fashion. How the synthesis and degradation of these second messengers are coupled is not fully understood. It has been previously demonstrated that the accumulation of intracellular cAMP inhibits irreversible attachment, and consequently decreases biofilm formation in P. aeruginosa [23,41]. More recently, Almblad and colleagues have described a subset of c-di-GMP PDEs that are involved in the cAMP-Vfr regulated suppression of c-di-GMP concentrations [23]. Therefore, an increase in cAMP concentrations can itself decrease c-di-GMP levels in P. aeruginosa, which in turn also inhibits biofilm formation $[5,23]$. On the other hand, high levels of c-di-GMP can decrease cAMP concentrations and suppress numerous acute virulence factors such as T2SS and T3SS, and type IV pili, although the detailed mechanisms of this regulatory pathway are still unknown [5].

To investigate the effect of $\mathrm{HCO}_{3}{ }^{-}$on biofilm formation in real-time, we applied an impedance-based detection method. In the field of microbiology, this approach is used to detect behavioral differences between biofilm and non-biofilm-producing strains [42], as well as to assess antiseptic [43] and antibiotic efficacy [44]. Data obtained by this method can be presented as either normalized cell index or $\Delta$ cell index [45]. Here we considered values of $\Delta$ cell index due to the noticeable drop in initial cell index (leading to negative $\Delta \mathrm{CI}$ values) in the presence of $\mathrm{HCO}_{3}{ }^{-}$. It should also be kept in mind that we performed these experiments in the presence of $5 \% \mathrm{CO}_{2}$ so that $\mathrm{BHI}$ medium alone or $\mathrm{BHI}$ medium supplemented with $\mathrm{NaCl}$ also contained small amounts of $\mathrm{HCO}_{3}{ }^{-}$which could have influenced bacterial growth and biofilm formation, although there is no indication of this in the results.

The observed reduction in $\Delta$ cell index in the RTCA measurements indicates that $\mathrm{NaHCO}_{3}(25$ and $50 \mathrm{mM}$ ) significantly decreases biofilm formation in both the ATCC strain and the clinical isolate at $48 \mathrm{~h}$ (Figure 2). It is also worth mentioning that $\Delta$ cell index gradually increased up to $24 \mathrm{~h}$ in the ATCC strain (Figure 2a,c), and the values were significantly higher in $\mathrm{BHI}$ medium supplemented with $\mathrm{NaCl}$, and with $\mathrm{NaHCO}_{3}$, than in the control medium. These data suggest that increased ionic strength may also influence initial bacterial adhesion.

Biofilm formation by P. aeruginosa is commonly assessed by crystal violet assay following at least $24 \mathrm{~h}$ incubation. Using the crystal violet assay, we were able to detect the inhibitory effects of $50 \mathrm{mM} \mathrm{NaHCO}_{3}$ on biofilm formation in the clinical isolate but not in the ATCC strain (Figure 3a,b). Although we had observed similar changes in bicarbonate- 
induced cyclic nucleotide concentrations in the two strains, other factors might be involved in determining their biofilm-forming capacity. There are inconsistent data in the literature regarding the biofilm-forming capacity of P. aeruginosa ATCC 27853 [46,47]. In addition, $P$. aeruginosa generally forms biofilms at an air-liquid interface which can be defined as floating biofilms [48-50]. Under these conditions, the cells produce a viscous matrix containing large amounts of water. Therefore, the crystal violet assay may not be reliable for quantifying P. aeruginosa biofilm formation, as has been previously suggested [51].

In a previous study, we reported that bicarbonate increased intracellular cAMP levels and decreased biofilm formation in P. aeruginosa [9]. Since the ELISA-based method used in that study was not suitable for detecting changes in c-di-GMP and cAMP concomitantly, we have applied the highly sensitive HPLC-MS technique in the present study. Furthermore, we have also used an impedance-based approach to assess the effects of bicarbonate on biofilm formation. As a further extension of our previous observations, we have examined the dose-dependence of the effects of $\mathrm{NaHCO}_{3}$ by using both 25 and $50 \mathrm{mM}$ concentrations.

Taken together, our findings indicate that $\mathrm{HCO}_{3}{ }^{-}$per se decreases intracellular c-diGMP in P. aeruginosa while increasing cAMP levels. These bicarbonate-induced reciprocal changes in second messenger concentrations inhibit biofilm formation. Although we show here that these effects of $\mathrm{HCO}_{3}{ }^{-}$were independent of $\mathrm{pH}$, the alkalization of the ASL that would accompany exogenous administration of $\mathrm{HCO}_{3}{ }^{-}$would also have the beneficial effect of reducing the viscosity of CF sputum [52,53], thereby facilitating mucociliary clearance. Importantly, both in vitro experimental [54] and in vivo clinical data [22] indicate that the application of bicarbonate is safe in CF. In addition, nebulized sodium bicarbonate has no adverse effect on airway smooth muscle [55]. Therefore, we propose that aerosolized $\mathrm{NaHCO}_{3}$ could be very effective as a supportive treatment in $\mathrm{CF}$, and possibly in other respiratory diseases associated with chronic bacterial infections and viscous mucus production, such as chronic obstructive pulmonary disease (COPD).

Author Contributions: Conceptualization, Á.Z., O.D., Z.M.L., M.A.D., and M.C.S.; methodology, K.R, B.S., G.T., P.H., I.G., R.T., and P.J.; investigation, K.R., B.S., G.T., P.H., I.G., R.T., and P.J.; formal analysis, K.R., I.G., and G.T.; writing—original draft preparation, K.R. and Á.Z.; writing-review and editing, Z.M.L., O.D., M.C.S., and Á.Z.; funding acquisition, Z.M.L., O.D., and Á.Z. All authors have read and agreed to the published version of the manuscript.

Funding: This research was funded by the Hungarian Human Resources Development Operational Program (EFOP-3.6.2-16-2017-00006 and EFOP-3.6.3-VEKOP-16-2017-00009; K.R., Z.M.L., and Á.Z.). Additional funding was received from the Thematic Excellence Program (2020-4.1.1.-TKP2020) of the Ministry for Innovation and Technology in Hungary within the framework of the Therapy Thematic Program at the Semmelweis University (Z.M.L. and Á.Z.). This work was also supported by the János Bolyai Research Scholarship of the Hungarian Academy of Sciences (G.T.) and the New National Excellence Program (UNKP-20-5) of the Ministry for Innovation and Technology (G.T.). Funding by the National Research, Development and Innovation Office, (NKFIH-PD:12827) is also acknowledged (R.T.).

Institutional Review Board Statement: Not applicable.

Informed Consent Statement: Not applicable.

Data Availability Statement: Data sharing is not applicable to this article.

Conflicts of Interest: The authors declare no conflict of interest.

\section{References}

1. Obritsch, M.D.; Fish, D.N.; MacLaren, R.; Jung, R. Nosocomial infections due to multidrug-resistant Pseudomonas aeruginosa: Epidemiology and treatment options. Pharmacotherapy 2005, 25, 1353-1364. [CrossRef]

2. Valentini, M.; Filloux, A. Biofilms and Cyclic di-GMP (c-di-GMP) signaling: Lessons from Pseudomonas aeruginosa and other bacteria. J. Biol. Chem. 2016, 291, 12547-12555. [CrossRef]

3. McDonough, K.A.; Rodriguez, A. The myriad roles of cyclic AMP in microbial pathogens: From signal to sword. Nat. Rev. Microbiol. 2012, 10, 27-38. [CrossRef] [PubMed] 
4. Hall, C.L.; Lee, V.T. Cyclic-di-GMP regulation of virulence in bacterial pathogens. Wiley Interdiscip. Rev. RNA 2018,9 , e1454. [CrossRef]

5. Almblad, H.; Harrison, J.J.; Rybtke, M.; Groizeleau, J.; Givskov, M.; Parsek, M.R.; Tolker-Nielsen, T. The cyclic AMP-Vfr signaling pathway in Pseudomonas aeruginosa is inhibited by cyclic Di-GMP. J. Bacteriol. 2015, 197, 2190-2200. [CrossRef]

6. Ha, D.-G.; O'Toole, G.A. c-di-GMP and its Effects on Biofilm Formation and Dispersion: A Pseudomonas Aeruginosa Review. Microbiol. Spectr. 2015, 3. [CrossRef]

7. Srivastava, D.; Waters, C.M. A tangled web: Regulatory connections between quorum sensing and cyclic Di-GMP. J. Bacteriol. 2012, 194, 4485-4493. [CrossRef] [PubMed]

8. Barraud, N.; Schleheck, D.; Klebensberger, J.; Webb, J.S.; Hassett, D.J.; Rice, S.A.; Kjelleberg, S. Nitric oxide signaling in Pseudomonas aeruginosa biofilms mediates phosphodiesterase activity, decreased cyclic di-GMP levels, and enhanced dispersal. J. Bacteriol. 2009, 191, 7333-7342. [CrossRef] [PubMed]

9. Dobay, O.; Laub, K.; Stercz, B.; Kéri, A.; Balázs, B.; Tóthpál, A.; Kardos, S.; Jaikumpun, P.; Ruksakiet, K.; Quinton, P.M.; et al. Bicarbonate Inhibits Bacterial Growth and Biofilm Formation of Prevalent Cystic Fibrosis Pathogens. Front. Microbiol. 2018, 9 , 2245. [CrossRef] [PubMed]

10. Dorschner, R.A.; Lopez-Garcia, B.; Peschel, A.; Kraus, D.; Morikawa, K.; Nizet, V.; Gallo, R.L. The mammalian ionic environment dictates microbial susceptibility to antimicrobial defense peptides. FASEB J. 2006, 20, 35-42. [CrossRef]

11. Farha, M.A.; French, S.; Stokes, J.M.; Brown, E.D. Bicarbonate Alters Bacterial Susceptibility to Antibiotics by Targeting the Proton Motive Force. ACS Infect. Dis. 2018, 4, 382-390. [CrossRef]

12. Pratten, J.; Wiecek, J.; Mordan, N.; Lomax, A.; Patel, N.; Spratt, D.; Middleton, A. Physical disruption of oral biofilms by sodium bicarbonate: An in vitro study. Int. J. Dent. Hyg. 2016, 14, 209-214. [CrossRef]

13. Jaikumpun, P.; Ruksakiet, K.; Stercz, B.; Pállinger, É.; Steward, M.; Lohinai, Z.; Dobay, O.; Zsembery, Á. Antibacterial Effects of Bicarbonate in Media Modified to Mimic Cystic Fibrosis Sputum. Int. J. Mol. Sci. 2020, 21, 8614. [CrossRef] [PubMed]

14. Gawande, P.V.; LoVetri, K.; Yakandawala, N.; Romeo, T.; Zhanel, G.G.; Cvitkovitch, D.G.; Madhyastha, S. Antibiofilm activity of sodium bicarbonate, sodium metaperiodate and SDS combination against dental unit waterline-associated bacteria and yeast. $J$. Appl. Microbiol. 2008, 105, 986-992. [CrossRef]

15. Malik, Y.S.; Goyal, S.M. Virucidal efficacy of sodium bicarbonate on a food contact surface against feline calicivirus, a norovirus surrogate. Int. J. Food Microbiol. 2006, 109, 160-163. [CrossRef]

16. Ratjen, F.; Bell, S.C.; Rowe, S.M.; Goss, C.H.; Quittner, A.L.; Bush, A. Cystic fibrosis. Nat. Rev. Dis. Prim. 2015, 1, 15010. [CrossRef] [PubMed]

17. Quinton, P.M. Role of epithelial HCO3- transport in mucin secretion: Lessons from cystic fibrosis. Am. J. Physiol. Cell Physiol. 2010, 299, C1222. [CrossRef]

18. Kunzelmann, K.; Schreiber, R.; Hadorn, H.B. Bicarbonate in cystic fibrosis. J. Cyst. Fibros. 2017, 16, 653-662. [CrossRef] [PubMed]

19. Quinton, P.M. Cystic fibrosis: Impaired bicarbonate secretion and mucoviscidosis. Lancet 2008, 372, 415-417. [CrossRef]

20. Haq, I.J.; Gray, M.A.; Garnett, J.P.; Ward, C.; Brodlie, M. Airway surface liquid homeostasis in cystic fibrosis: Pathophysiology and therapeutic targets. Thorax 2016, 71, 284-287. [CrossRef] [PubMed]

21. Bhagirath, A.Y.; Li, Y.; Somayajula, D.; Dadashi, M.; Badr, S.; Duan, K. Cystic fibrosis lung environment and Pseudomonas aeruginosa infection. BMC Pulm. Med. 2016, 16, 174. [CrossRef]

22. Gomez, C.C.S.; Parazzi, P.L.F.; Clinckspoor, K.J.; Mauch, R.M.; Pessine, F.B.T.; Levy, C.E.; Peixoto, A.O.; Ribeiro, M.Â.G.O.; Ribeiro, A.F.; Conrad, D.; et al. Safety, Tolerability, and Effects of Sodium Bicarbonate Inhalation in Cystic Fibrosis. Clin. Drug Investig. 2020, 40, 105-117. [CrossRef] [PubMed]

23. Almblad, H.; Rybtke, M.; Hendiani, S.; Andersen, J.B.; Givskov, M.; Tolker-Nielsen, T. High levels of cAMP inhibit Pseudomonas aeruginosa biofilm formation through reduction of the c-di-GMP content. Microbiology 2019, 165, 324-333. [CrossRef]

24. Opoku-Temeng, C.; Zhou, J.; Zheng, Y.; Su, J.; Sintim, H.O. Cyclic dinucleotide (c-di-GMP, c-di-AMP, and cGAMP) signalings have come of age to be inhibited by small molecules. Chem. Commun. 2016, 52, 9327-9342. [CrossRef]

25. Sambanthamoorthy, K.; Sloup, R.E.; Parashar, V.; Smith, J.M.; Kim, E.E.; Semmelhack, M.F.; Neiditch, M.B.; Waters, C.M. Identification of small molecules that antagonize diguanylate cyclase enzymes to inhibit biofilm formation. Antimicrob. Agents Chemother. 2012, 56, 5202-5211. [CrossRef]

26. Kimura, Y.; Okazaki, N.; Takegawa, K. Enzymatic characteristics of two novel Myxococcus xanthus enzymes, PdeA and PdeB, displaying $3^{\prime}, 5^{\prime}$ - and $2^{\prime}, 3^{\prime}$-cAMP phosphodiesterase, and phosphatase activities. FEBS Lett. 2009, 583, 443-448. [CrossRef] [PubMed]

27. Topal, H.; Fulcher, N.B.; Bitterman, J.; Salazar, E.; Buck, J.; Levin, L.R.; Cann, M.J.; Wolfgang, M.C.; Steegborn, C. Crystal structure and regulation mechanisms of the $\mathrm{CyaB}$ adenylyl cyclase from the human pathogen pseudomonas aeruginosa. J. Mol. Biol. 2012, 416, 271-286. [CrossRef]

28. Petrova, O.E.; Sauer, K. High-performance liquid chromatography (HPLC)-based detection and quantitation of cellular c-di-GMP. Methods Mol. Biol. 2017, 1657, 33-43. [CrossRef]

29. Burhenne, H.; Kaever, V. Quantification of cyclic dinucleotides by reversed-phase LC-MS/MS. In Cyclic Nucleotide Signaling in Plants Methods and Protocols; Gehring, C., Ed.; Humana Press Inc.: Tortowa, NJ, USA, 2013; Volume 1016, pp. 27-37. ISBN 9781627034401. 
30. Shukla, S.K.; Rao, T.S. An Improved Crystal Violet Assay for Biofilm Quantification in 96-Well Microtitre Plate. bioRxiv 2017. [CrossRef]

31. Wenderska, I.B.; Chong, M.; McNulty, J.; Wright, G.D.; Burrows, L.L. Palmitoyl-dl-Carnitine is a multitarget inhibitor of Pseudomonas aeruginosa biofilm development. ChemBioChem 2011, 12, 2759-2766. [CrossRef] [PubMed]

32. Jenal, U.; Reinders, A.; Lori, C. Cyclic di-GMP: Second messenger extraordinaire. Nat. Rev. Microbiol. 2017, 15, 271-284. [CrossRef]

33. Koestler, B.J.; Waters, C.M. Intestinal GPS: Bile and bicarbonate control cyclic di-GMP to provide Vibrio cholerae spatial cues within the small intestine. Gut Microbes 2014, 5, 775-780. [CrossRef]

34. Evans, T.J. Small colony variants of Pseudomonas aeruginosa in chronic bacterial infection of the lung in cystic fibrosis. Future Microbiol. 2015, 10, 231-239. [CrossRef] [PubMed]

35. Rohde, M. Small-Colony Variants of Pseudomonas aeruginosa in Cystic Fibrosis. Clin. Infect. Dis. 1999, 29, 621-625. [CrossRef]

36. Blanka, A.; Düvel, J.; Dötsch, A.; Klinkert, B.; Abraham, W.R.; Kaever, V.; Ritter, C.; Narberhaus, F.; Häussler, S. Constitutive production of c-di-GMP is associated with mutations in a variant of Pseudomonas aeruginosa with altered membrane composition. Sci. Signal. 2015, 8, ra36. [CrossRef]

37. Malone, J.G.; Jaeger, T.; Spangler, C.; Ritz, D.; Spang, A.; Arrieumerlou, C.; Kaever, V.; Landmann, R.; Jenal, U. YfiBNR Mediates Cyclic di-GMP Dependent Small Colony Variant Formation and Persistence in Pseudomonas aeruginosa. PLoS Pathog. 2010, 6, e1000804. [CrossRef]

38. Malone, J.G. Role of small colony variants in persistence of Pseudomonas aeruginosa infections in cystic fibrosis lungs. Infect. Drug Resist. 2015, 8, 237-247. [CrossRef] [PubMed]

39. Chen, Y.; Cann, M.J.; Litvin, T.N.; Iourgenko, V.; Sinclair, M.L.; Levin, L.R.; Buck, J. Soluble adenylyl cyclase as an evolutionarily conserved bicarbonate sensor. Science 2000, 289, 625-628. [CrossRef] [PubMed]

40. Kobayashi, M.; Buck, J.; Levin, L.R. Conservation of functional domain structure in bicarbonate-regulated "soluble" adenylyl cyclases in bacteria and eukaryotes. Dev. Genes Evol. 2004, 214, 503-509. [CrossRef]

41. Ono, K.; Oka, R.; Toyofuku, M.; Sakaguchi, A.; Hamada, M.; Yoshida, S.; Nomura, N. CAMP signaling affects irreversible attachment during biofilm formation by pseudomonas aeruginosa PAo1. Microbes Environ. 2014, 29, 104-106. [CrossRef]

42. Gutiérrez, D.; Hidalgo-Cantabrana, C.; Rodríguez, A.; García, P.; Ruas-Madiedo, P. Monitoring in Real Time the Formation and Removal of Biofilms from Clinical Related Pathogens Using an Impedance-Based Technology. PLoS ONE 2016, 11, e0163966. [CrossRef]

43. Junka, A.F.; Janczura, A.; Smutnicka, D.; Mączyńska, B.; Secewicz, A.; Nowicka, J.; Bartoszewicz, M.; Gościniak, G. Use of the real time xCelligence system for purposes of medical microbiology. Polish J. Microbiol. 2012, 61, 191-197. [CrossRef]

44. Ferrer, M.D.; Rodriguez, J.C.; Álvarez, L.; Artacho, A.; Royo, G.; Mira, A. Effect of antibiotics on biofilm inhibition and induction measured by real-time cell analysis. J. Appl. Microbiol. 2017, 122, 640-650. [CrossRef]

45. Kho, D.; MacDonald, C.; Johnson, R.; Unsworth, C.; O'Carroll, S.; Mez, E.; Angel, C.; Graham, E. Application of xCELLigence RTCA Biosensor Technology for Revealing the Profile and Window of Drug Responsiveness in Real Time. Biosensors 2015, 5 , 199-222. [CrossRef]

46. Cao, H.; Lai, Y.; Bougouffa, S.; Xu, Z.; Yan, A. Comparative genome and transcriptome analysis reveals distinctive surface characteristics and unique physiological potentials of Pseudomonas aeruginosa ATCC 27853. BMC Genom. 2017, 18. [CrossRef] [PubMed]

47. Perez, L.R.R.; Costa, M.C.N.; Freitas, A.L.P.; Barth, A.L. Evaluation of biofilm production by pseudomonas aeruginosa isolates recovered fromcystic fibrosis and non-cystic fibrosis patients. Braz. J. Microbiol. 2011, 42, 476-479. [CrossRef] [PubMed]

48. Alhede, M.; Kragh, K.N.; Qvortrup, K.; Allesen-Holm, M.; van Gennip, M.; Christensen, L.D.; Jensen, P.Ø.; Nielsen, A.K.; Parsek, M.; Wozniak, D.; et al. Phenotypes of non-attached pseudomonas aeruginosa aggregates resemble surface attached biofilm. PLoS ONE 2011, 6, 27943. [CrossRef] [PubMed]

49. Caiazza, N.C.; O'Toole, G.A. SadB is required for the transition from reversible to irreversible attachment during biofilm formation by Pseudomonas aeruginosa PA14. J. Bacteriol. 2004, 186, 4476-4485. [CrossRef]

50. Friedman, L.; Kolter, R. Genes involved in matrix formation in Pseudomonas aeruginosa PA14 biofilms. Mol. Microbiol. 2004, 51, 675-690. [CrossRef]

51. Peeters, E.; Nelis, H.J.; Coenye, T. Comparison of multiple methods for quantification of microbial biofilms grown in microtiter plates. J. Microbiol. Methods 2008, 72, 157-165. [CrossRef]

52. Stigliani, M.; Manniello, M.D.; Zegarra-Moran, O.; Galietta, L.; Minicucci, L.; Casciaro, R.; Garofalo, E.; Incarnato, L.; Aquino, R.P.; Del Gaudio, P.; et al. Rheological Properties of Cystic Fibrosis Bronchial Secretion and In Vitro Drug Permeation Study: The Effect of Sodium Bicarbonate. J. Aerosol Med. Pulm. Drug Deliv. 2016, 29, 337-345. [CrossRef]

53. Ferrera, L.; Capurro, V.; Delpiano, L.; Gianotti, A.; Moran, O. The Application of Bicarbonate Recovers the Chemical-Physical Properties of Airway Surface Liquid in Cystic Fibrosis Epithelia Models. Biology 2021, 10, 278. [CrossRef] [PubMed]

54. Gróf, I.; Bocsik, A.; Harazin, A.; Santa-Maria, A.R.; Vizsnyiczai, G.; Barna, L.; Kiss, L.; Fưr, G.; Rakonczay, Z.; Ambrus, R.; et al. The effect of sodium bicarbonate, a beneficial adjuvant molecule in cystic fibrosis, on bronchial epithelial cells expressing a wild-type or mutant CFTR channel. Int. J. Mol. Sci. 2020, 21. [CrossRef] [PubMed]

55. Kis, A.; Toth, L.A.; Kunos, L.; Vasas, S.; Losonczy, G.; Mendes, E.; Wanner, A.; Horvath, G. The effect of airway alkalization by nebulized sodium bicarbonate on airway blood flow. Eur. Respir. J. 2012, 40, 2143. 